Check for updates

Cite this: Food Funct., 2018, 9, 160

\section{Chemical composition and bioactive properties of the wild mushroom Polyporus squamosus (Huds.) Fr: a study with samples from Romania}

\author{
Andrei Mocan, ${ }^{\text {a, }}$ Ângela Fernandes, ${ }^{a}$ Lillian Barros, (D) a Gianina Crişan, ${ }^{b}$ \\ Marija Smiljković, ${ }^{c}$ Marina Soković (D) ${ }^{c}$ and Isabel C. F. R. Ferreira (D)*a
}

Received 28th September 2017 Accepted 6th November 2017

DOI: $10.1039 / \mathrm{c} 7 \mathrm{fo} 01514 \mathrm{c}$

rsc.li/food-function

\begin{abstract}
In Eastern Europe, wild mushrooms are widely collected in mountain areas and used for their medicinal properties or as healthy foods. This study aimed at determining the chemical composition (nutritional value, free sugars, organic acids, phenolic compounds, fatty acids and tocopherols) and bioactive properties (antioxidant, antimicrobial and antiquorum sensing) of wild Polyporus squamosus (Huds.) Fr from Romania. The results indicate that the fruiting bodies of $P$. squamosus are rich in carbohydrates $(74.22 \mathrm{~g}$ per $100 \mathrm{~g} \mathrm{dw}$ ) and proteins (18.7 g per $100 \mathrm{~g} \mathrm{dw}$ ). Trehalose was the main free sugar, while malic acid was the organic acid detected in the highest amount ( $2.21 \mathrm{~g}$ per $100 \mathrm{~g} \mathrm{dw}$ ), and p-hydroxybenzoic acid was the main phenolic compound. Among tocopherols, $\beta$-tocopherol was the most abundant form $(114.7 \mu \mathrm{g}$ per $100 \mathrm{~g} \mathrm{dw}$ ). Additionally, regarding the fatty acids' pattern, polyunsaturated acids represent more than $57 \%$ of all fatty acids, followed by monounsaturated fatty acids (24.96\%). The highest measured antioxidant effect of $P$. squamosus extract was found using the TBARS inhibition assay $\left(E_{50}=0.22 \mathrm{mg} \mathrm{mL}^{-1}\right.$ ), followed by the $\beta$-carotene/linoleate assay $\left(\mathrm{EC}_{50}=1.41 \mathrm{mg} \mathrm{mL}^{-1}\right)$. A minimal inhibitory concentration of the tested extracts was obtained between $0.61-20.4 \mathrm{mg} \mathrm{mL}^{-1}$, while the bactericidal effect was achieved between 1.2-40.8 $\mathrm{mg} \mathrm{mL}^{-1}$. Antibiofilm potential was obtained at all tested concentrations, and subinhibitory concentrations of the extract exhibited an antiquorum effect and reduced the formation of $P$. aeruginosa pili, which all together influenced the virulence of this bacterium. Due to the investigated bioactivities and compounds of $P$. squamosus and its well-balanced nutritional profile, this mushroom can be further used as a medicinal ingredient based on its antioxidative and antimicrobial potential.
\end{abstract}

\section{Introduction}

Over the last decade dietary habits have progressively changed, at a global scale, with nutraceuticals, functional foods and food supplements receiving an increasing demand from consumers, and consequently gaining scientific interest from academia. ${ }^{1}$ Nowadays considering the extensive evidence of health-promoting abilities of different food classes, great attention is given by the consumers and food industry to natural foods, especially to wild foods coming from unpolluted areas (i.e. mountains). ${ }^{2,3}$ Wild edibles include annual and

\footnotetext{
${ }^{a}$ Centro de Investigação de Montanha (CIMO), Instituto Politécnico de Bragança, Campus de Santa Apolónia, 5300-253 Bragança, Portugal. E-mail: iferreira@ipb.pt; Fax: +351-273-325405; Tel: +351-273-303219

${ }^{b}$ Department of Pharmaceutical Botany, "Iuliu Hațieganu" University of Medicine and Pharmacy, 23 Gheorghe Marinescu Street, 400337 Cluj-Napoca, Romania 'University of Belgrade, Institute for Biological Research "Siniša Stanković", Department of Plant Physiology, Bulevar Despota Stefana 142, 11000 Belgrade, Serbia
}

perennial herbs, forbs, vines, sedges and rushes, grasses, broadleaved and needle-like or scale-like leaved shrubs, trees, ferns, as well as mushrooms, algae and lichens., ${ }^{2,4}$

Mushrooms possess an important nutritional value since they are quite rich in proteins, having a high content of essential amino acids and fibers, and being poor in fat. Moreover, edible mushrooms represent important sources of vitamins (B1, B2, B12, C, D, and E). ${ }^{5-8}$ Additionally, they represent an important source of different bioactive compounds such as unsaturated fatty acids, phenolic compounds, terpenoids, and carotenoids, and can be ultimately developed into functional foods, nutraceuticals or pharmaceutical products, taking advantage of their unique chemical features and the advantage of the additive and synergistic effects of all their panel of bioactive compounds..$^{5,8-13}$

The usage of wild edible mushrooms in cooking, traditional medicine, and religious rituals is a very well established and appreciated practice which has been maintained and developed in different cultures and civilizations around the world, particularly in South and Central-Eastern Europe, 
China, Mexico and Latin America. ${ }^{14-17}$ Moreover, the consumption of wild growing mushrooms is currently preferred to eating of cultivated fungi in many countries of Central and Eastern Europe. ${ }^{18}$ Collecting them is very popular in numerous regions in the mountain areas, representing an important component of the human diet, and the main proportion amongst other wild foods. ${ }^{19}$ However, despite a lack of accurate data about the use of wild mushrooms, it is estimated that their consumption may reach several kilograms per person per year.

The several changes in the environmental factors have an important impact on human health currently, which is reflected in the production of free radical species which are linked to the damage of vital biomolecules or cell structures (DNA, proteins and membranes). ${ }^{20}$ Furthermore, this physiological condition is associated with the development of serious ailments such as cardiovascular and neurodegenerative diseases, and different forms of cancers. Besides their nutritional value, compounds from mushrooms can act as antioxidant, antitumor, antiviral, antimicrobial, and immunomodulatory agents. ${ }^{11,21-27}$ Moreover, they have been shown to be modulators of the immune system and to exert hypoglycemic, antithrombotic, antibiotic, antiviral, antihypertensive, and antilipidemic properties, as well as anti-inflammatory and antimicrobial actions. ${ }^{28-30}$

Several vitamins and minerals such as ascorbic acid, niacin, riboflavin, thiamine and some essential micronutrients were described in species of the genus Polyporus. Polyporus squamosus (Huds.) Fr is an edible mushroom at an early and tender stage, used frequently as a spice, and being widely distributed in Europe, Asia, North America and Australia. ${ }^{24}$ Polyporus species are well used medicinal mushrooms being described to possess diuretic, cytotoxic, nephroprotective, hepatoprotective, immuno-enhancing, anti-inflammatory, antioxidative, hair-growing, and antimicrobial activities. ${ }^{31-35}$ Particularly, P. squamosus was shown to possess antioxidant, ${ }^{36-38}$ immunomodulating, ${ }^{39}$ antibacterial, ${ }^{37}$ antifungal $^{24}$ properties as well as antibiofilm and anti-quorum sensing activities. ${ }^{24}$ Moreover, there are some studies reporting the chemical composition of P. squamosus fruiting bodies from Portugal, Serbia, and Turkey. ${ }^{24,36,40,41}$

Different mushrooms are investigated by the scientific community, in searching for new therapeutic alternatives, and many results proved their bioactive properties as well as their medicinal value. ${ }^{11,13,21,25,28,29,34,39,42,43}$ The mountainous area of Romania, due to climatic conditions and flora diversity, is one of the European regions with high wild edible mushroom diversity, many of them being medicinal as well. Despite of their great popularity, data regarding the chemical composition and bioactive properties of the wild mushrooms available in the region as well as their nutritional value are very meager. Therefore, the aim of the present study was to provide a comprehensive study on the chemical composition of P. squamosus collected from Romania as well as on some of its biological activities (antioxidant, antimicrobial, and antiquorum sensing).

\section{Materials and methods}

\subsection{Standards and reagents}

The following chemicals were of HPLC grade and obtained from Lab-Scan (Lisbon, Portugal): acetonitrile 99.9\%, $n$-hexane 95\% and ethyl acetate $99.8 \%$. All other chemicals including methanol were of analytical grade and obtained from common providers. Fatty acid methyl ester (FAME) reference standard mixture 37 (standard 47885-U) was purchased from Sigma (St Louis, MO, USA), as well as sugar standards, organic acids, phenolic acids, and Trolox (6-hydroxy-2,5,7,8-tetramethylchroman-2-carboxylic acid). Tocol and tocopherol standards were purchased from Matreya (Pleasant Gap, PA, USA). 2,2Diphenyl-1-picrylhydrazyl (DPPH) was obtained from Alfa Aesar (Ward Hill, MA, USA). Water was treated in a Milli-Q water purification system (TGI Pure Water Systems, USA). Mueller-Hinton agar (MH) and malt agar (MA) were obtained from the Institute of Immunology and Virology, Torlak (Belgrade, Serbia).

\subsection{Mushroom samples}

Fruiting bodies (tender stage) of P. squamosus were collected from the Apuseni mountain region, Sartăş, Alba County, Transylvania, Romania in May 2017, and authenticated by Dr Andrei Mocan, Senior Lecturer at the Department of Pharmaceutical Botany, "Iuliu Hațieganu" University of Medicine and Pharmacy, Cluj-Napoca, Romania, and a voucher specimen was deposited at the herbarium of the Department of Pharmaceutical Botany, "Iuliu Hațieganu" University of Medicine and Pharmacy. Fresh and cleaned fruiting bodies were randomly divided and dried using a laboratory plant dryer at $25{ }^{\circ} \mathrm{C}$ until reaching a constant mass. Afterwards, the mushroom material was ground into a fine powder using a laboratory mill, mixed to obtain a homogeneous sample, and kept at $4{ }^{\circ} \mathrm{C}$, for further analyses. All assays were carried out three times (three separate samplings) and in triplicate, and the values reported are represented as average and standard deviation (SD).

\subsection{Extraction procedure}

The ground powder mushroom material (1.5 g) was stirred with methanol $(30 \mathrm{~mL})$ at $25^{\circ} \mathrm{C}$ at $150 \mathrm{rpm}$ for $1 \mathrm{~h}$, and further filtered through Whatman no. 4 paper. Additionally, the residue was further extracted with an additional portion of methanol. After combining the two fractions, the methanolic extracts were evaporated using a rotary evaporator (Büchi R-210; Flawil, Switzerland) under reduced pressure, redissolved in methanol at a concentration of $40 \mathrm{mg} \mathrm{mL}$ (stock solution), and stored at $4{ }^{\circ} \mathrm{C}$ for further analyses (HPLC-DAD-ESI/MS and antioxidant assays). ${ }^{42}$ For the evaluation of antimicrobial activity, the dry extract was dissolved in $5 \%$ DMSO $\left(1 \mathrm{mg} \mathrm{mL}^{-1}\right)$, following the procedure mentioned in section 2.6 . 


\subsection{Chemical characterization}

2.4.1. Nutritional and energetic value. The nutritional value of the mushroom sample was analyzed using AOAC procedures concerning the composition in proteins, fat, carbohydrates and ash. ${ }^{44}$ For the estimation of the crude protein content $(N \times 4.38)$ the macro-Kjeldahl method was used; the crude fat content was determined by extracting a known weight of sample with petroleum ether using a Soxhlet apparatus while the ash content was determined by calcination at $600 \pm 15^{\circ} \mathrm{C}$. The total carbohydrate content was calculated by difference and total energy was calculated according to the following equation: Energy $(\mathrm{kcal})=4 \times(\mathrm{g}$ protein $+\mathrm{g}$ carbohydrates $)+9 \times(\mathrm{g}$ fat $)$.

2.4.2. Determination of free sugars. Free individual sugars were assessed from the fruiting body by high performance liquid chromatography coupled to a refraction index detector (HPLC-RI, Knauer, Smartline system 1000; Berlin, Germany). The extraction procedure and HPLC analysis were assessed using the procedures previously described. ${ }^{45,46}$ The identification of the sugars was performed by comparing the relative retention times of sample peaks with standards under the same chromatographic conditions and the obtained data were analyzed using Clarity 2.4 Software (DataApex, Podohradska, Czech Republic). The internal standard (IS, melezitose) method was used, and the quantification was based on the RI signal response of each standard. The results were expressed in $\mathrm{g}$ per $100 \mathrm{~g}$ of dry weight $(\mathrm{dw})$.

2.4.3. Determination of phenolic compounds. The abovementioned extract was diluted to a concentration of 10 $\mathrm{mg} \mathrm{mL}^{-1}$ and filtered through a $0.22 \mu \mathrm{m}$ nylon filter before chromatographic analysis. The individual phenolic acids were determined by using a Dionex Ultimate 3000 UPLC system (Thermo Scientific, San Jose, CA, USA) as previously described. ${ }^{42,47}$ DAD detection was carried out using $280 \mathrm{~nm}$ as a preferred wavelength, while further structural analysis was assessed using a mass spectrometer (MS). The MS detection was performed in the negative mode, using a Linear Ion Trap LTQ XL mass spectrometer (ThermoFinnigan, San Jose, CA, USA) equipped with an electrospray ionization (ESI) source. The phenolic acids were characterized according to their UV and MS spectra and retention times, in comparison with authentic standards when available. For quantitative analysis, calibration curves were prepared from different standard compounds. The quantitative results were expressed as mg per $100 \mathrm{~g}$ of dry weight fruiting body (dw).

2.4.4. Determination of organic acids. The individual organic acids were determined following a procedure previously described. ${ }^{48}$ Briefly, the analysis was performed using a Shimadzu 20A Series UFLC (Shimadzu Corporation, Kyoto, Japan). The detection was carried out using a diode array detector (DAD), at $215 \mathrm{~nm}$ and $245 \mathrm{~nm}$ as preferred wavelengths. The organic acids found were quantified using calibration curves obtained for each commercial compound. The results were expressed in $\mathrm{g}$ per $100 \mathrm{~g}$ of dried weight (dw) fruiting body.
2.4.5. Determination of fatty acids. The fatty acid composition was evaluated after a transesterification procedure as previously described. ${ }^{45,46}$ The profile of the fatty acids was analyzed with a DANI 1000 gas chromatograph (GC) with a flame ionization detector (FID). The identification of the fatty acids was assessed by comparing the relative retention times of FAME peaks from samples with standards. Finally, the results were recorded and processed using Clarity 4.0.1.7 Software (DataApex, Podohradska, Czech Republic). The results were expressed in relative percentage of each fatty acid.

2.4.6. Determination of tocopherols. The tocopherol content was assessed as previously described, ${ }^{6}$ using an HPLC system (Knauer, Smartline system 1000; Berlin, Germany) coupled with a fluorescence detector (FP-2020; Jasco, Oklahoma City, OK, USA). Individual compounds were identified by comparison with authentic standards under the same chromatographic conditions. By using the internal standard method (tocol, IS), the quantification was based on the fluorescence signal response, and the tocopherol content was expressed in $\mu \mathrm{g}$ per $100 \mathrm{~g}$ of dried weight (dw).

\subsection{Evaluation of antioxidant activity}

2.5.1. General. The antioxidant activity was evaluated through several assays based on different mechanisms, and successive dilutions were made from the stock solution and subjected to in vitro assays as already described ${ }^{49}$ to evaluate the antioxidant activity of the samples. The sample concentrations providing $50 \%$ of antioxidant activity or 0.5 of absorbance $\left(\mathrm{EC}_{50}\right)$ were calculated from the graphs of antioxidant activity percentages (DPPH, $\beta$-carotene/linoleate and TBARS assays) or absorbance at $690 \mathrm{~nm}$ (reducing power assay) against sample concentrations. Commercially available Trolox was used as a reference standard.

2.5.2. Folin-Ciocalteu assay. One $\mathrm{mL}$ of the extractive solution was mixed with $5 \mathrm{~mL}$ Folin-Ciocalteu reagent (previously diluted $1: 10, \mathrm{v} / \mathrm{v}$ with water) and sodium carbonate $\left(75 \mathrm{~g} \mathrm{~L}^{-1}\right.$, $4 \mathrm{~mL}$ ). The tubes were vortexed for $15 \mathrm{~s}$ and allowed to incubate for $30 \mathrm{~min}$ at $40{ }^{\circ} \mathrm{C}$, followed by the absorbance measurement at $765 \mathrm{~nm}$ (Analytikjena spectrophotometer; Jena, Germany). The commercially available gallic acid was used as a standard. The reduction of the Folin-Ciocalteu reagent was expressed in $\mathrm{mg}$ of gallic acid equivalents (GAE) per $g$ of extract.

2.5.3. Reducing power or ferricyanide/Prussian blue assay. This assay was performed using a microplate reader and the capacity of the sample to convert $\mathrm{Fe}^{3+}$ into $\mathrm{Fe}^{2+}$ was evaluated. Briefly, the extract solutions with different concentrations $(0.5 \mathrm{~mL})$ were mixed with sodium phosphate buffer $(200 \mathrm{mmol}$ $\left.\mathrm{L}^{-1}, \mathrm{pH} 6.6,0.5 \mathrm{~mL}\right)$ and potassium ferricyanide $(1 \% \mathrm{w} / \mathrm{v}$, $0.5 \mathrm{~mL}$ ). The mixture was incubated at $50{ }^{\circ} \mathrm{C}$ for $20 \mathrm{~min}$, and trichloroacetic acid $(10 \% \mathrm{w} / \mathrm{v}, 0.5 \mathrm{~mL})$ was further added. Furthermore, the mixture $(0.8 \mathrm{~mL})$ was pipetted in a 48 -well plate. The procedure was repeated with deionized water as a blank $(0.8 \mathrm{~mL})$ and ferric chloride $(0.1 \% \mathrm{w} / \mathrm{v}, 0.16 \mathrm{~mL})$, and afterwards the absorbance was measured at $690 \mathrm{~nm}$ using an 
ELX800 microplate reader (Bio-Tek Instruments, Inc.; Winooski, VT, USA).

2.5.4. DPPH radical-scavenging activity assay. Briefly, $30 \mu \mathrm{L}$ of the extract and $270 \mu \mathrm{L}$ of methanol containing DPPH radicals $\left(6 \times 10^{-5} \mathrm{~mol} \mathrm{~L}^{-1}\right)$ were pipetted and mixed in a 96 wellplate. The reaction mixture was incubated in the dark for $30 \mathrm{~min}$ at room temperature, and the absorption was measured at $515 \mathrm{~nm}$ using a microplate reader. ${ }^{42}$ The DPPH radical scavenging activity (RSA) was calculated as a percentage of DPPH discolouration using the following equation: $\% \mathrm{RSA}=$ $\left[\left(A_{\mathrm{DPPH}}-A_{\mathrm{S}}\right) / A_{\mathrm{DPPH}}\right] \times 100$, where $A_{\mathrm{S}}$ is the absorbance of the sample and $A_{\mathrm{DPPH}}$ is the absorbance of the DPPH solution.

2.5.5. Inhibition of $\boldsymbol{\beta}$-carotene bleaching or $\boldsymbol{\beta}$-carotene/ linoleate assay. The neutralization of linoleate free radicals evaluated through the $\beta$-carotene/linoleate assay avoids $\beta$-carotene bleaching, and was used to measure the antioxidant capacity of the sample. Briefly, a solution of $\beta$-carotene was prepared by dissolving $2 \mathrm{mg}$ of $\beta$-carotene in $10 \mathrm{~mL}$ chloroform. Furthermore, $2 \mathrm{~mL}$ of this solution were pipetted into a roundbottom flask. The chloroform was removed at $40{ }^{\circ} \mathrm{C}$ under vacuum using a rotary evaporator and $40 \mathrm{mg}$ linoleic acid, $400 \mathrm{mg}$ Tween 80 emulsifier, and $100 \mathrm{~mL}$ distilled water were added to the flask under vigorous shaking. Aliquots $(4.8 \mathrm{~mL})$ of this emulsion were transferred into test tubes containing $0.2 \mathrm{~mL}$ of a range of concentrations of the extract. The tubes were shaken and incubated in a water bath at $50{ }^{\circ} \mathrm{C}$. The zero time absorbance was measured at $470 \mathrm{~nm}$ (AnalytikJena, Jena, Germany), immediately after the emulsion was added to each tube. ${ }^{5}$

2.5.6. Thiobarbituric acid reactive substance (TBARS) assay. Porcine (Sus scrofa) brains were obtained from officially slaughtered animals, dissected, and further homogenized with a Polytron homogenizer in ice cold Tris-HCl buffer $(20 \mathrm{mM}$, $\mathrm{pH} 7.4$ ) to yield a $1: 2 \mathrm{w} / \mathrm{v}$ brain tissue homogenate. ${ }^{42}$ The porcine brain homogenate was centrifuged for $10 \mathrm{~min}$ at $3000 \mathrm{~g}$, and afterwards an $100 \mu \mathrm{L}$ aliquot of the supernatant was incubated for $1 \mathrm{~h}$ at $37^{\circ} \mathrm{C}$ with $200 \mu \mathrm{L}$ samples of a range of concentrations of the extract in the presence of $\mathrm{FeSO}_{4}$ $(10 \mathrm{mM} ; 100 \mu \mathrm{L})$ and ascorbic acid $(0.1 \mathrm{mM} ; 100 \mu \mathrm{L})$. After the incubation time, the reaction was stopped by adding $500 \mu \mathrm{L}$ trichloroacetic acid $(28 \% \mathrm{w} / \mathrm{v})$, followed by $380 \mu \mathrm{L}$ thiobarbituric acid (TBA, 2\%, w/v). The mixture was then incubated again for $20 \mathrm{~min}$ at $80{ }^{\circ} \mathrm{C}$. Afterwards, the samples were centrifuged at $3000 \mathrm{~g}$ for $10 \mathrm{~min}$ to remove the precipitated proteins, and the absorbance of the malondialdehyde (MDA)-TBA complex in the supernatant was measured at $532 \mathrm{~nm}$. Using the following equation the inhibition ratio (\%) was calculated: Inhibition ratio $(\%)=[(A-B) / A] \times 100 \%$, where $A$ and $B$ were the absorbance of the control and the sample solution, respectively. ${ }^{50}$

\subsection{Evaluation of the antimicrobial activity}

2.6.1. Antibacterial activity. The following Gram-negative bacteria were used: Escherichia coli (ATCC 35210), Pseudomonas aeruginosa (ATCC 27853), Salmonella typhimurium (ATCC 13311), Listeria monocytogenes (NCTC 7973), Enterococcus faecalis (human isolate) and the following Gram-positive bacteria: Bacillus cereus (clinical isolate), Micrococcus flavus (ATCC 10240) and Staphylococcus aureus (ATCC 6538). Bioassay is carried out by the microdilution method.

The bacterial cell suspension was adjusted with sterile saline to a concentration of approximately $1.0 \times 10^{5}$ in a final volume of $100 \mu \mathrm{L}$ per well. The extract was dissolved in 5\% DMSO (1 mg mL ${ }^{-1}$ ) and added into a Tryptic Soy broth (TSB) medium $(100 \mu \mathrm{L})$ with bacterial inoculum $\left(1.0 \times 10^{4} \mathrm{CFU}\right.$ per well) to achieve the desired concentration. The microplates were incubated using a rotary shaker $(160 \mathrm{rpm})$ for $24 \mathrm{~h}$ at $37^{\circ}$ C. The following day, $30 \mu \mathrm{L}$ of $0.2 \mathrm{mg} \mathrm{mL}^{-1}$ solution of INT ( $p$-iodonitrotetrazolium violet) was added, and the plates were returned to the incubator for at least one-half hour to ensure an adequate colour reaction. ${ }^{51,52}$ The inhibition of growth was indicated by a clear solution or a definite decrease in color reaction. The lowest concentrations without visible growth (using the binocular microscope) were defined as concentrations that completely inhibited bacterial growth (MICs). The MBCs were determined by serial sub-cultivation of $2 \mu \mathrm{L}$ of the extract into microtitre plates containing $100 \mu \mathrm{L}$ of broth per well and further incubation for $24 \mathrm{~h}$. The lowest concentration with no visible growth was defined as the $\mathrm{MBC}$, indicating 99.5\% killing of the original inoculum. The optical density of each well was measured at a wavelength of $655 \mathrm{~nm}$ by microplate manager 4.0 (Bio-Rad Laboratories) and compared with a blank and the positive control. The antibiotics streptomycin and ampicillin were used as positive controls $\left(1 \mathrm{mg} \mathrm{mL}^{-1}\right.$ in sterile physiological saline). Three independent experiments were performed in triplicate.

\subsubsection{Antiquorum and antibiofilm activity}

Bacterial strains, growth media and culture conditions. P. aeruginosa PA01 (ATCC 27853) used in this study is from the collection of the Mycoteca, Institute for Biological Research "Sinisa Stankovic", Belgrade, Serbia. Bacteria were routinely grown in Luria-Bertani (LB) medium (1\% w/v NaCl, 1\% w/v tryptone, $0.5 \% \mathrm{w} / \mathrm{v}$ yeast extract) with shaking $(220 \mathrm{rpm})$ and cultured at $37^{\circ} \mathrm{C}$.

Biofilm formation. The effect of different concentrations of extract (ranging from 0.5 to 0.125 of $\mathrm{MIC}$, MIC was $0.2 \mathrm{mg} \mathrm{mL}^{-1}$ ) on biofilm forming ability was tested on polystyrene flatbottomed microtitre 96 well plates as described in ref. 53 and 54 with some modifications. Briefly, $100 \mu \mathrm{L}$ of overnight culture of $P$. aeruginosa (inoculum size was $1 \times 10^{8} \mathrm{CFU} \mathrm{mL}^{-1}$ ) was added to each well of the plates in the presence of $100 \mu \mathrm{L}$ subinhibitory concentrations (subMIC) of extract $(0.5,0.25$ and $0.125 \mathrm{MIC}$ ) or $100 \mathrm{~mL}$ medium (control). After incubation for $24 \mathrm{~h}$ at $37^{\circ} \mathrm{C}$, each well was washed twice with sterile PBS ( $\mathrm{pH} 7.4$ ), dried, and stained for $10 \mathrm{~min}$ with $0.1 \%$ crystal violet in order to determine the biofilm mass. After drying, $200 \mu \mathrm{L}$ of $95 \%$ ethanol $(\mathrm{v} / \mathrm{v})$ was added to solubilize the dye that had stained the biofilm cells. The excess stain was washed off with $\mathrm{dH}_{2} \mathrm{O}$. After $10 \mathrm{~min}$, the content of the wells was homogenized and the absorbance at $\lambda=625 \mathrm{~nm}$ was read on a Sunrise ${ }^{\mathrm{TM}}$ Tecan ELISA reader (Mannedorf, Switzerland). The experiment was done in triplicate and repeated two times and values were presented as mean values $\pm \mathrm{SE}$. 
Inhibition of biofilm formation of $P$. aeruginosa. P. aeruginosa was cultured overnight at $37^{\circ} \mathrm{C}$ in LB medium and adjusted to

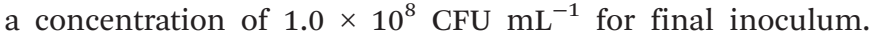
Filter paper discs (Whatman; $4 \mathrm{~mm}$ in diameter) were impregnated with a solution of $P$. squamosus extract $(0.125,0.25$, $0.5 \mathrm{mg}$ per disc), streptomycin and ampicillin (0.125, 0.25, $0.5 \mathrm{mg}$ per disc). Discs were dried at room temperature $(3 \mathrm{~h}$, protected from light), and aseptically placed onto the plates prior inoculated with $P$. aeruginosa $\left(1 \times 10^{8} \mathrm{CFU} \mathrm{mL}^{-1}\right)$. Petri dishes were placed for incubation in a thermostat at $37^{\circ} \mathrm{C}$ for 24 h. After incubation, whether inhibition or antiquorum zones were obtained was recorded. Minimal inhibitory concentrations were determined as a diameter of the growth clear inhibition zones around the discs (no growth at all), while antiquorum, i.e., antibiofilm zones were determined as transparent zones around the discs (growth with different characteristics) behind the margin of the inhibition zone. ${ }^{55}$ The experiment was done in triplicate and repeated two times and values were presented as mean values $\pm \mathrm{SE}$.

Inhibition of twitching and flagellar motility of $P$. aeruginosa. After growth in the presence or absence of $P$. squamosus extract (subMIC $0.15 \mathrm{mg} \mathrm{mL}^{-1}$ ), streptomycin and ampicillin (subMIC $0.15 \mathrm{mg} \mathrm{mL}^{-1}$ ), the cells of $P$. aeruginosa PA01 were washed twice with sterile PBS and re-suspended in PBS at $1 \times 10^{8} \mathrm{CFU}$ $\mathrm{mL}^{-1}$ (OD of 0.1 at $660 \mathrm{~nm}$ ). Briefly, the cells were stabbed into a nutrient agar plate with a sterile toothpick and incubated overnight at $37{ }^{\circ} \mathrm{C}$. The plates were then removed from the incubator and incubated at room temperature for two more days. Colony edges and the zone of motility were measured with a light microscope. ${ }^{55,56}$ Fifty microlitres of P. squamosus extract was mixed into $10 \mathrm{~mL}$ of molten $\mathrm{MH}$ (Mueller-Hinton) agar medium and poured immediately over the surface of a solidified LB agar plate as an overlay. The plate was point inoculated with an overnight culture of PAO1 once the overlaid agar had solidified and incubated at $37^{\circ} \mathrm{C}$ for 3 days. The extent of swimming was determined by measuring the area of the colony. The experiment was done in triplicate and repeated two times. The colony diameters were measured three times in different directions and the values were presented as mean values $\pm \mathrm{SE}$.

Inhibition of synthesis of $P$. aeruginosa PA01 pyocyanin. Overnight culture of $P$. aeruginosa PA01 was diluted to $\mathrm{OD}_{600} \mathrm{~nm}$ 0.2. Then, P. squamosus extract $(250 \mu \mathrm{L}), 0.125 \mathrm{MIC}$ (0.025 mg mL $\left.\mathrm{mL}^{-1}\right), 0.25 \mathrm{MIC}\left(0.05 \mathrm{mg} \mathrm{mL}^{-1}\right)$ and $0.5 \mathrm{MIC}$ $\left(0.10 \mathrm{mg} \mathrm{mL} \mathrm{mL}^{-1}\right)$ were added to $P$. aeruginosa $(4.75 \mathrm{~mL})$ and incubated at $37^{\circ} \mathrm{C}$ for $24 \mathrm{~h}$. The treated culture was extracted with chloroform $(3 \mathrm{~mL})$, followed by mixing the chloroform layer with $0.2 \mathrm{M} \mathrm{HCl}(1 \mathrm{~mL})$. Absorbance of the extracted organic layer was measured at $520 \mathrm{~nm}$ using a Shimadzu UV1601 spectrophotometer (Kyoto, Japan). ${ }^{57}$ The experiment was done in triplicate and repeated two times. The values for OD were presented as mean values $\pm \mathrm{SE}$.

2.6.3. Antifungal activity. For the antifungal bioassays, following fungi were used: Aspergillus fumigatus (plant isolate), Aspergillus niger (ATCC 6275), Aspergillus versicolor (ATCC 11730), Aspergillus ochraceus (ATCC 12066), Penicillium funiculosum
(ATCC 36839), Penicillium ochrochloron (ATCC 9112), Penicillium verrucosum (food isolate) and Trichoderma viride (IAM 5061). Bioassay is carried out by the microdilution method. The fungal spores were washed from the surface of agar plates with sterile $0.85 \%$ saline containing $0.1 \%$ Tween 80 $(\mathrm{v} / \mathrm{v})$. The spore suspension was adjusted with sterile saline to a concentration of approximately $1.0 \times 10^{5}$ in a final volume of $100 \mu \mathrm{l}$ per well. Minimum inhibitory concentration (MIC) determinations were performed by a serial dilution technique using 96-well microtiter plates. The extract was dissolved in $5 \%$ DMSO (1 $\mathrm{mg} \mathrm{mL} \mathrm{m}^{-1}$ ) and added in Sabouraud broth medium (SDA) $(100 \mu \mathrm{L})$ with bacterial inoculum $\left(1.0 \times 10^{4} \mathrm{CFU}\right.$ per well) to achieve the desired concentration. The microplates were incubated using a rotary shaker $(160 \mathrm{rpm})$ for $24 \mathrm{~h}$ at $28^{\circ}$ C. The lowest concentrations without visible growth (using the binocular microscope) were defined as MICs. The fungicidal concentrations (MFCs) were determined by serial subcultivation of a $2 \mu \mathrm{l}$ of sample into microtiter plates containing $100 \mu \mathrm{l}$ of broth per well and further incubation for $72 \mathrm{~h}$ at $28{ }^{\circ} \mathrm{C}$. The lowest concentration with no visible growth was defined as MFC indicating $99.5 \%$ killing of the original inoculums. ${ }^{58}$ Each experiment was repeated in triplicate. Commercial fungicides, ketoconazole and bifonazole were used as positive controls $\left(0.10-3.50 \mathrm{mg} \mathrm{mL}^{-1}\right)$.

\section{Results and discussion}

\subsection{Chemical composition of Polyporus squamosus}

Research on the chemical composition of P. squamosus was conducted to target different classes of bioactive compounds. To the best of our knowledge, this is the first study referring to the chemical composition of $P$. squamosus fruiting bodies originating from Romania. Results concerning the nutritional value and individual sugars are presented in Table 1. Carbohydrates were the most abundant class of macronutrients with $74.22 \mathrm{~g}$ per $100 \mathrm{~g}$ dw, followed by proteins $(18.7 \mathrm{~g}$ per $100 \mathrm{~g} \mathrm{dw})$, ash (5.7 $\mathrm{g}$ per $100 \mathrm{~g} \mathrm{dw})$, and fat (1.46 g per $100 \mathrm{~g}$ $\mathrm{dw}$ ), having an energetic value of $384.7 \mathrm{kcal}$ per $100 \mathrm{~g} \mathrm{dw}$. The fruiting body of $P$. squamosus represents a very good low-fat medicinal food which can be used on a regular basis. The

Table 1 Nutritional value and free sugar composition of Polyporus squamosus (mean $\pm \mathrm{SD}$ )

\begin{tabular}{ll}
\hline & Polyporus squamosus \\
\hline Fat $(\mathrm{g}$ per $100 \mathrm{~g} \mathrm{dw})$ & $1.46 \pm 0.02$ \\
Protein $(\mathrm{g}$ per $100 \mathrm{~g} \mathrm{dw})$ & $18.7 \pm 0.1$ \\
Ash $(\mathrm{g}$ per $100 \mathrm{~g}$ dw) & $5.7 \pm 0.1$ \\
Carbohydrates $(\mathrm{g}$ per $100 \mathrm{~g} \mathrm{dw})$ & $74.22 \pm 0.01$ \\
Energetic value $(\mathrm{kcal}$ per $100 \mathrm{~g} \mathrm{dw})$ & $384.7 \pm 0.4$ \\
Sugars $(\mathrm{g}$ per $\mathbf{1 0 0} \mathrm{g}$ dw) & \\
Fructose & $0.730 \pm 0.004$ \\
Mannitol & $1.05 \pm 0.02$ \\
Trehalose & $6.81 \pm 0.03$ \\
Sum & $8.59 \pm 0.06$ \\
& \\
dw - dry weight. &
\end{tabular}


nutritional composition of $P$. squamosus from the present study was similar to one of the specimens collected from Northeast Portugal (Bragança) and Northern Serbia, where carbohydrates and proteins were also described as being the most abundant macronutrients. ${ }^{24}$ Additionally, our results are in line with the findings of Akata et al. who reported a similar trend in macronutrient composition: carbohydrates $65.24 \%$, proteins $13.32 \%$, fat $3.98 \%$, and ash $7.14 \% .{ }^{36}$

Regarding sugar composition, trehalose was the most abundant compound (6.81 g per $100 \mathrm{~g} \mathrm{dw}$ ), while fructose was found in the smallest amount ( $0.730 \mathrm{~g}$ per $100 \mathrm{~g} \mathrm{dw})$. In a previous study conducted by our team on $P$. squamosus fruiting bodies originating from Portugal and Serbia, trehalose was also found as being the most abundant sugar, while rhamnose, not detected in the herein sample, was found in the smallest amount, for both samples. ${ }^{24}$ Among organic acids, it was possible to identify oxalic, quinic, malic and fumaric acids (Table 2). Malic acid was detected in the highest amount $(2.21 \mathrm{~g}$ per $100 \mathrm{~g} \mathrm{dw})$, whilst fumaric and oxalic acids were detected in much lower amounts $(0.0003 \mathrm{~g}$ per $100 \mathrm{~g} \mathrm{dw}$, and $0.076 \mathrm{~g}$ per $100 \mathrm{~g} \mathrm{dw}$ ). In a similar manner to our results, malic acid was described as being the most abundant organic acid in samples of $P$. squamosus originating from Portugal and Serbia, while quinic acid was not detected. ${ }^{24}$ An important fact is that the presence of these compounds in foods not only influences their flavor, but also the stability, acceptability and shelf-life. ${ }^{59}$ Moreover, organic acids present in natural matrices are involved in the reduction of oxidative stress. ${ }^{60}$

Phenolic compounds which contribute directly to antioxidative protection and play an important role in stabilizing lipid peroxidation were also determined in the studied sample, ${ }^{11}$ being identified as $p$-hydroxybenzoic acid and p-coumaric acid (Table 2). Similarly, Fernandes et al. ${ }^{24}$ described $p$-hydroxybenzoic acid as the main phenolic acid in samples of $P$. squamosus of different origins, while cinnamic acid, a phenolic-related compound, was also found in small amounts.

Lipophilic compounds, including fatty acids and tocopherols, were also characterized (Table 3), and twenty-three fatty acids were identified, both saturated and unsaturated. The fatty acids determined in high percentages were linoleic (C18:2n6), oleic (C18:1n9) and palmitic (C16:0) acids.

Table 2 Organic and phenolic acids of Polyporus squamosus (mean \pm $\mathrm{SD})$

\begin{tabular}{ll}
\hline $\begin{array}{l}\text { Organic acids (g per } \mathbf{1 0 0} \mathbf{g} \mathbf{~ d w}) \\
\text { Oxalic acid }\end{array}$ & \\
Quinic acid & $0.076 \pm 0.001$ \\
Malic acid & $1.40 \pm 0.02$ \\
Fumaric acid & $2.21 \pm 0.01$ \\
Total organic acids & $0.0003 \pm 0.0001$ \\
Phenolic acids $(\mathbf{m g}$ per $\mathbf{1 0 0} \mathbf{g} \mathbf{d w})$ & $3.69 \pm 0.04$ \\
p-Hydroxybenzoic acid & \\
p-Coumaric acid & $2.03 \pm 0.05$ \\
Total phenolic compounds & $0.272 \pm 0.002$ \\
Related compounds $(\mathbf{m g}$ per $\mathbf{1 0 0} \mathbf{g} \mathbf{~ d w})$ & $2.34 \pm 2.26$ \\
Cinnamic acid & \\
\end{tabular}

dw - dry weight.
Table 3 Fatty acid and tocopherol composition of Polyporus squamosus (mean $\pm \mathrm{SD}$ )

\begin{tabular}{ll}
\hline & Polyporus squamosus \\
\hline C6:0 & $0.033 \pm 0.001$ \\
C10:0 & $0.025 \pm 0.001$ \\
C12:0 & $0.049 \pm 0.002$ \\
C14:0 & $0.246 \pm 0.001$ \\
C14:1 & $0.011 \pm 0.001$ \\
C15:0 & $1.09 \pm 0.01$ \\
C16:0 & $13.40 \pm 0.07$ \\
C16:1 & $0.83 \pm 0.01$ \\
C17:0 & $0.123 \pm 0.002$ \\
C18:0 & $1.20 \pm 0.02$ \\
C18:1n9 & $22.27 \pm 0.01$ \\
C18:2n6 & $56.55 \pm 0.04$ \\
C18:3n3 & $0.441 \pm 0.005$ \\
C20:0 & $0.132 \pm 0.001$ \\
C20:1 & $0.151 \pm 0.001$ \\
C20:2 & $0.161 \pm 0.003$ \\
C20:3n3 + C21:0 & $0.16 \pm 0.01$ \\
C20:5n3 & $0.059 \pm 0.006$ \\
C22:0 & $1.04 \pm 0.03$ \\
C22:1n9 & $0.36 \pm 0.02$ \\
C23:0 & $0.10 \pm 0.01$ \\
C24:0 & $0.235 \pm 0.004$ \\
C24:1 & $1.34 \pm 0.02$ \\
Total SFA (\% of total FA) & $17.68 \pm 0.04$ \\
Total MUFA (\% of total FA) & $24.96 \pm 0.01$ \\
Total PUFA (\% of total FA) & $57.37 \pm 0.03$ \\
Tocopherols $(\mu \mathrm{g}$ per 100 g dw) & \\
$\alpha$-Tocopherol & \\
$\beta$-Tocopherol & $1.54 \pm 0.05$ \\
8-Tocopherol & $114.7 \pm 0.8$ \\
Total tocopherols & $5.3 \pm 0.5$ \\
& $3.7 \pm 0.4$ \\
& $125.2 \pm 0.6$ \\
& \\
\hline
\end{tabular}

SFA - saturated fatty acids; MUFA - monounsaturated fatty acids; PUFA - polyunsaturated fatty acids.

Moreover, polyunsaturated fatty acids, which are known to possess several health beneficial effects, were found to be predominant in P. squamosus $(57.37 \%)$, followed by monounsaturated fatty acids $(24.96 \%)$, and saturated fatty acids $(17.68 \%)$. In the previous report of Fernandes et $a l^{24}$ a similar fatty acid pattern was described in P. squamosus from different origins, being C18:2n6, C18:1n9 and C16:0 the main fatty acids.

Tocopherols are known to be powerful natural antioxidants, and are present in natural sources usually as a mixture of four isomers (namely $\alpha-, \beta-, \gamma-$, and $\delta$-tocopherol). ${ }^{10,49} \alpha-, \beta-, \gamma$ - and $\delta$-Tocopherols were found in the analyzed sample, and $\beta$-tocopherol was determined in the highest amount $(114.7 \mu \mathrm{g}$ per $100 \mathrm{~g} \mathrm{dw}$ ). Interestingly, $\beta$-tocopherol was also described as the dominant tocopherol in $P$. squamosus originating from Portugal, while $\gamma$-tocopherol was predominate for the Serbian originating sample. According to Fernandes et $a .^{24}$ these differences could be ascribed to natural variability inherent to samples grown under different environmental conditions.

\subsection{Antioxidant activity of Polyporus squamosus extract}

The maintenance of equilibrium between free radical production and antioxidant defenses is an essential condition for normal organism functioning, and an eventual imbalance is 
Table 4 Antioxidant activity of the Polyporus squamosus extract (mean \pm SD)

\begin{tabular}{|c|c|c|c|c|}
\hline \multicolumn{2}{|l|}{ Reducing power } & \multicolumn{2}{|l|}{ Radical scavenging activity } & \multirow[t]{2}{*}{ Lipid peroxidation inhibition } \\
\hline $\begin{array}{l}\text { Folin-Ciocalteu } \\
\text { (mg GAE per } \mathrm{g} \text { extract) }\end{array}$ & $\begin{array}{l}\text { Ferricyanide/Prussian } \\
\text { blue }\left(\mathrm{EC}_{50} ; \mathrm{mg} \mathrm{mL}^{-1}\right)\end{array}$ & $\begin{array}{l}\text { DPPH scavenging } \\
\text { activity }\left(\mathrm{EC}_{50} ; \mathrm{mg} \mathrm{mL}^{-1}\right)\end{array}$ & $\begin{array}{l}\beta \text {-Carotene/linoleate } \\
\left(\mathrm{EC}_{50} ; \mathrm{mg} \mathrm{mL}^{-1}\right)\end{array}$ & \\
\hline $17.9 \pm 0.1$ & $2.35 \pm 0.02$ & $8.2 \pm 0.1$ & $1.41 \pm 0.01$ & $0.22 \pm 0.01$ \\
\hline
\end{tabular}

Concerning the Folin-Ciocalteu assay, higher values mean higher reducing power; for the other assays, the results are presented in $\mathrm{EC}_{50}$ values, which means that higher values correspond to lower reducing power or antioxidant potential. $\mathrm{EC}_{50}$ : extract concentration corresponding to $50 \%$ of antioxidant activity or 0.5 of absorbance for the ferricyanide/Prussian blue assay. Trolox EC 50 values: $0.041 \mathrm{mg} \mathrm{mL}^{-1}$ (reducing power), $0.042 \mathrm{mg} \mathrm{mL}^{-1}$ (DPPH scavenging activity), $0.018 \mathrm{mg} \mathrm{mL}^{-1}$ ( $\beta$-carotene bleaching inhibition) and $0.023 \mathrm{mg} \mathrm{mL}^{-1}$ (TBARS inhibition).

reflected through the accumulation of damaged cell structures (cell membranes, proteins). Compounds from wild mushrooms have been described as excellent natural antioxidants. ${ }^{11}$ In the present study, the antioxidant activity of $P$. squamosus was evaluated through five assays involving different mechanisms: reducing power, radical scavenging activity and lipid peroxidation inhibition (Table 4). For the radical scavenging (DPPH scavenging activity), lipid peroxidation inhibition (TBARS, $\beta$-carotene/linoleate) and reducing power activities (ferricyanide/Prussian blue assay) the results are presented in $\mathrm{EC}_{50}$ values, indicating that higher values correspond to lower reducing potential (ferricyanide/Prussian blue) or antioxidant potential, whereas for the Folin-Ciocalteu assay (which measures the reducing power of the extract in relation to the molybdenum ion present in the Folin-Ciocalteu reagent), higher values indicate higher reducing power. ${ }^{61}$ As seen in Table 4, the highest measured antioxidant effect of P. squamosus extract was found in the TBARS inhibition assay $\left(\mathrm{EC}_{50}=0.22 \mathrm{mg} \mathrm{mL}{ }^{-1}\right)$, followed by $\beta$-carotene/linoleate $\left(\mathrm{EC}_{50}=\right.$ $1.41 \mathrm{mg} \mathrm{mL} \mathrm{m}^{-1}$ ), ferricyanide/Prussian blue reducing activity $\left(\mathrm{EC}_{50}=2.35 \mathrm{mg} \mathrm{mL}{ }^{-1}\right)$, and $\mathrm{DPPH}$ scavenging activity $\left(\mathrm{EC}_{50}=\right.$ $8.2 \mathrm{mg} \mathrm{mL} \mathrm{m}^{-1}$ ). A similar trend was observed in the study of Fernandes et al., ${ }^{24}$ in which the highest antioxidant effect of P. squamosus extracts from different origins was also measured for the TBARS inhibition assay. Nevertheless, other authors have previously reported higher DPPH scavenging and reducing power activities in P. squamosus from Turkey. ${ }^{36,38}$

\subsection{Antimicrobial activity of Polyporus squamosus extract}

The results of the antimicrobial activity indicate that $P$. squamosus extract possesses a good antibacterial activity on
E. cloacae and B. cereus, while the extract was not active on the tested fungi. Additionally, according to the previous findings of Fernandes et al., $S$. aureus was the most sensitive strain to P. squamosus extract with a MIC value of $0.20 \mathrm{mg} \mathrm{mL}^{-1}$ and a $\mathrm{MBC}$ value of only $0.39 \mathrm{mg} \mathrm{mL} \mathrm{m}^{-1}$, which are much more lower as the results presented herein for the same strain. ${ }^{24}$ Moreover, the bacteriostatic concentration of $P$. squamosus extract for $P$. aeruginosa was determined by the microdilution method to be $0.6-20.4 \mathrm{mg} \mathrm{mL}^{-1}$ and the bactericidal concentration is from $1.2-40.8 \mathrm{mg} \mathrm{mL}^{-1}$ (Table 5).

The effect of $P$. squamosus extract on biofilm formation of P. aeruginosa was tested with $10.0 \mathrm{mg}$ (0.5 MIC), $5.0 \mathrm{mg}$ (0.25 $\mathrm{MIC})$ and $2.5 \mathrm{mg} \mathrm{mL}^{-1}(0.125 \mathrm{MIC})$. Under the concentration of 0.5 MIC of tested extract only $36.0 \%$ of $P$. aeruginosa biofilm was inhibited, ampicillin inhibited $30.9 \%$ and streptomycin $50.7 \%$ of biofilm formation. P. squamosus extract at 0.25 MIC inhibited $35.5 \%$ of biofilm formation, and ampicillin and streptomycin $43.5 \%$ and $29 \%$, respectively. The lowest concentration of extract, 0.125 MIC inhibited biofilm formation of $4 \%$, ampicillin of $7.8 \%$ and streptomycin $11.4 \%$ (Table 6 ).

The extract of $P$. squamosus was tested for the twitching motility effect on the $P$. aeruginosa colony and producing of pili. The untreated colonies of $P$. aeruginosa were flat with a

Table 6 Percentage of inhibition of biofilm formation after treatment with subinhibitory concentrations of sample (mean \pm SD)

\begin{tabular}{llrr}
\hline & $1 / 2 \mathrm{MIC}$ & \multicolumn{1}{c}{$1 / 4 \mathrm{MIC}$} & \multicolumn{1}{c}{$1 / 8 \mathrm{MIC}$} \\
\hline$P$. squamosus & $36.0 \pm 1.50$ & $35.5 \pm 1.80$ & $4.0 \pm 0.08$ \\
Ampicillin & $30.9 \pm 2.40$ & $43.5 \pm 2.10$ & $7.8 \pm 0.06$ \\
Streptomycin & $50.7 \pm 3.80$ & $29.0 \pm 0.90$ & $11.4 \pm 0.09$
\end{tabular}

Table 5 Antibacterial activities of the $P$. squamosus extract $\left(\mathrm{mg} \mathrm{mL}^{-1}\right.$, mean $\left.\pm \mathrm{SD}\right)$

\begin{tabular}{|c|c|c|c|c|c|c|c|c|c|}
\hline & & $\begin{array}{l}\text { Micrococcus } \\
\text { flavus }\end{array}$ & $\begin{array}{l}\text { Salmonella } \\
\text { typhimurium }\end{array}$ & $\begin{array}{l}\text { Escherichia } \\
\text { coli }\end{array}$ & $\begin{array}{l}\text { Enterobacter } \\
\text { cloacae }\end{array}$ & $\begin{array}{l}\text { Listeria } \\
\text { monocytogenes }\end{array}$ & Bacillus cereus & $\begin{array}{l}\text { Staphylococcus } \\
\text { aureus }\end{array}$ & $\begin{array}{l}\text { Pseudomonas } \\
\text { aeruginosa }\end{array}$ \\
\hline \multirow[t]{2}{*}{ P. squamosus } & MIC & $10.2 \pm 0.02$ & $20.4 \pm 0.09$ & $20.4 \pm 0.05$ & $0.61 \pm 0.02$ & $20.4 \pm 0.02$ & $1.2 \pm 0.02$ & $20.4 \pm 0.05$ & $20.4 \pm 0.08$ \\
\hline & MBC & $20.4 \pm 0.02$ & $40.8 \pm 0.06$ & $40.8 \pm 0.06$ & $1.2 \pm 0.03$ & $40.8 \pm 0.20$ & $2.4 \pm 0.03$ & $40.8 \pm 0.60$ & $40.8 \pm 0.80$ \\
\hline \multirow[t]{2}{*}{ Ampicillin } & MIC & $0.13 \pm 0.03$ & $0.13 \pm 0.03$ & $0.18 \pm 0.03$ & $0.17 \pm 0.02$ & $0.20 \pm 0.03$ & $0.17 \pm 0.02$ & $0.10 \pm 0.01$ & $0.40 \pm 0.03$ \\
\hline & MBC & $0.15 \pm 0.05$ & $0.20 \pm 0.03$ & $0.27 \pm 0.02$ & $0.20 \pm 0.06$ & $0.33 \pm 0.05$ & $0.20 \pm 0.06$ & $0.20 \pm 0.06$ & $0.67 \pm 0.08$ \\
\hline \multirow[t]{2}{*}{ Streptomycin } & MIC & $0.07 \pm 0.06$ & $0.17 \pm 0.01$ & $0.13 \pm 0.03$ & $0.03 \pm 0.00$ & $0.22 \pm 0.06$ & $0.03 \pm 0.00$ & $0.13 \pm 0.02$ & $0.13 \pm 0.03$ \\
\hline & MBC & $0.17 \pm 0.03$ & $0.27 \pm 0.00$ & $0.20 \pm 0.05$ & $0.07 \pm 0.00$ & $0.40 \pm 0.08$ & $0.07 \pm 0.00$ & $0.30 \pm 0.03$ & $0.23 \pm 0.02$ \\
\hline
\end{tabular}

MIC - Minimum inhibitory concentrations; MBC - minimum bactericidal concentrations. 


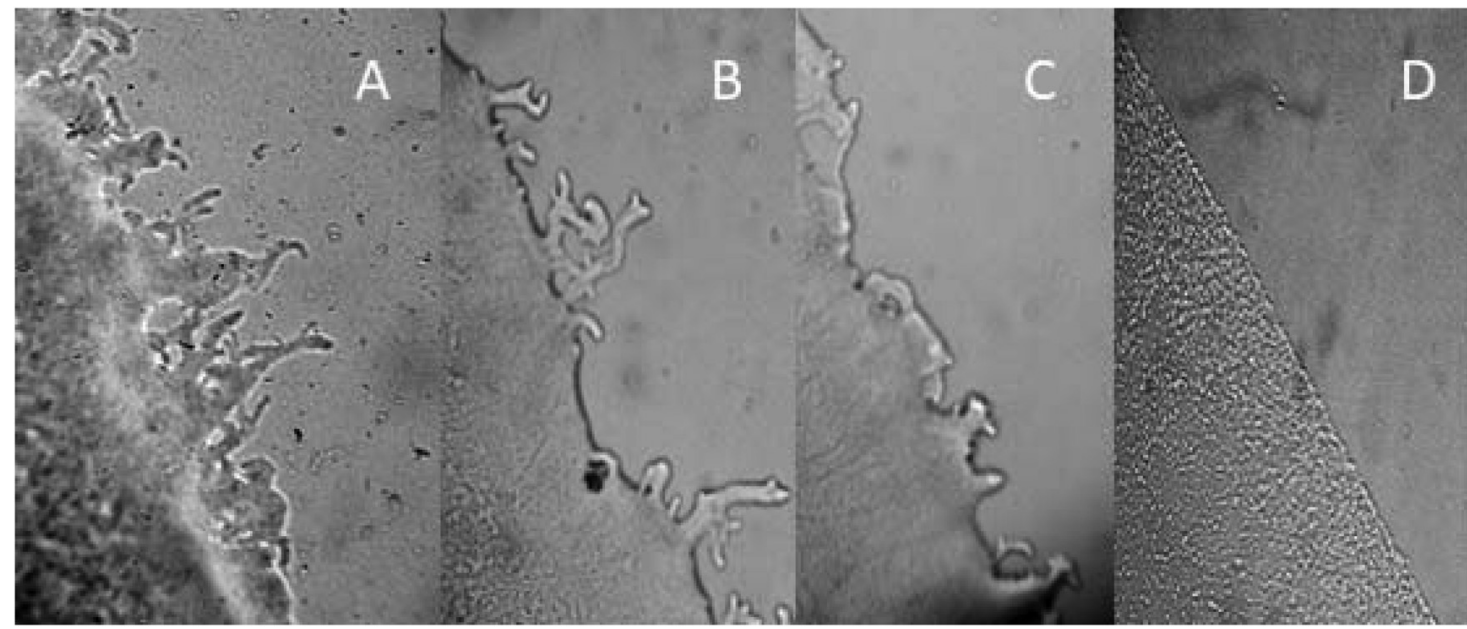

Fig. 1 Light microscopy of colony edges of $P$. aeruginosa in twitching motility, grown in the presence or absence of $P$. squamosus extracts. (A) $P$. aeruginosa produced a flat, widely spread, irregularly shaped colony in the absence of extracts; (B) the colonies from the bacteria grown with extract in concentration of 0.25 MIC, reduced hazy zone surrounding the colony; (C) P. aeruginosa colony in the presence of extract of $0.5 \mathrm{MIC}$; (D) streptomycin in concentration of 0.5 , without flagella. Magnification: (A-D) $\times 100$.

Table 7 Reduction of pyocinin pigment production of $P$. aeruginosa PAO1 after treatment with $1 / 2$ MIC concentrations of samples $($ mean $\pm \mathrm{SD})$

\begin{tabular}{ll}
\hline & $\%$ of inhibition \\
\hline P. squamosus & No \\
Ampicillin & $19.0 \pm 0.80$ \\
Streptomycin & $21.0 \pm 0.60$
\end{tabular}

No - no effect.

rough appearance displaying irregular colony edges (Fig. 1A) and a hazy zone surrounding the colony. It can be noted that extract applied in 0.25 MIC on $P$. aeruginosa colony influenced the reduction of twitching and bacteria produced almost round, smooth, irregular colony edges, and the pili were reduced both in size and in numbers, (Fig. 1B). The reduction of pili and changes in their shape and size were more obvious at a concentration of extract in $0.5 \mathrm{MIC}$, (Fig. 1C). Streptomycin reduced the pili completely (Fig. 1D).

The concentrations of 0.5 MIC P. squamosus extract were tested for antipyocyanin production by $P$. aeruginosa. At the tested concentrations of the extract the green pigment content was not decreased. Ampicillin (19\%) and streptomycin (21\%) also possessed very low potential in reduction of pyocyanin production (Table 7).

\section{Conclusions}

An in-depth chemical analysis of several classes of compounds revealed fruiting bodies of $P$. squamosus from Romania as a rich source of bioactive molecules with potent in vitro activities. According to the obtained results, P. squamosus represents a source of polyunsaturated fatty acids and $\beta$-tocopherol.
Moreover, the biological properties of $P$. squamosus indicate that it might be further explored as a medicinal mushroom in the composition of different pharmaceuticals as well as a dietary supplement. Nonetheless, further studies are needed to elucidate the different mechanisms of action involved as well as the specific compounds responsible for the tested biological activities.

\section{Conflicts of interest}

There are no conflicts to declare.

\section{Acknowledgements}

The authors are grateful to the Foundation for Science and Technology (FCT, Portugal) and FEDER under Programme PT2020 for financial support to CIMO (UID/AGR/00690/2013), L. Barros research contract and A. Feitor (SFRH/BPD/114753/ 2016) grant. The authors are also grateful to the Interreg España-Portugal for financial support through the project 0377_Iberphenol_6_E. The authors are grateful to the Serbian Ministry of Education, Science and Technological Development for financial support (grant number 173032).

\section{References}

1 B. Bigliardi and F. Galati, Innovation trends in the food industry: The case of functional foods, Trends Food Sci. Technol., 2013, 31, 118-129.

2 A. M. Carvalho and A. M. Barata, in Wild Plants, Mushrooms and Nuts: Functional Food Properties and Applications, 
ed. Isabel C. F. R. Ferreira, P. Morales and L. Barros, John Wiley \& Sons, Ltd., 2017, pp. 159-198.

3 N. Martins and I. C. F. R. Ferreira, Mountain food products: A broad spectrum of market potential to be exploited, Trends Food Sci. Technol., 2017, 67, 12-18.

4 J. Pinela, M. Carocho, M. I. Dias, C. Caleja, L. Barros and I. C. F. R. Ferreira, in Wild Plants, Mushrooms and Nuts: Functional Food Properties and Applications, ed. I. C. F. R. Ferreira, P. Morales and L. Barros, John Wiley \& Sons, Ltd., 2017, pp. 315-351.

5 F. S. Reis, L. Barros, A. Martins and I. C. F. R. Ferreira, Chemical composition and nutritional value of the most widely appreciated cultivated mushrooms: An inter-species comparative study, Food Chem. Toxicol., 2012, 50, 191-197.

6 S. A. Heleno, L. Barros, M. J. Sousa, A. Martins and I. C. F. R. Ferreira, Tocopherols composition of Portuguese wild mushrooms with antioxidant capacity, Food Chem., 2010, 119, 1443-1450.

7 L. Barros, M. J. Ferreira, B. Queirós, I. C. F. R. Ferreira and P. Baptista, Total phenols, ascorbic acid, $\beta$-carotene and lycopene in Portuguese wild edible mushrooms and their antioxidant activities, Food Chem., 2007, 103, 413-419.

8 L. Barros, T. Cruz, P. Baptista, L. M. Estevinho and I. C. F. R. Ferreira, Wild and commercial mushrooms as source of nutrients and nutraceuticals, Food Chem. Toxicol., 2008, 46, 2742-2747.

9 L. Barros, P. Baptista and I. C. F. R. Ferreira, Effect of Lactarius piperatus fruiting body maturity stage on antioxidant activity measured by several biochemical assays, Food Chem. Toxicol., 2007, 45, 1731-1737.

10 L. Barros, D. M. Correia, I. C. F. R. Ferreira, P. Baptista and C. Santos-Buelga, Optimization of the determination of tocopherols in Agaricus sp. edible mushrooms by a normal phase liquid chromatographic method, Food Chem., 2008, 110, 1046-1050.

11 I. C. F. R. Ferreira, L. Barros and R. M. V. Abreu, Antioxidants in wild mushrooms., Curr. Med. Chem., 2009, 16, 1543-1560.

12 E. Pereira, L. Barros, A. Martins and I. C. F. R. Ferreira, Towards chemical and nutritional inventory of Portuguese wild edible mushrooms in different habitats, Food Chem., 2012, 130, 394-403.

13 O. Taofiq, S. A. Heleno, R. C. Calhelha, M. J. Alves, L. Barros, A. M. González-Paramás, M. F. Barreiro and I. C. F. R. Ferreira, The potential of Ganoderma lucidum extracts as bioactive ingredients in topical formulations, beyond its nutritional benefits, Food Chem. Toxicol., 2017, 108, 139-147.

14 C. V. Toledo, C. Barroetaveñ, Â. Fernandes, L. Barros and I. C. F. R. Ferreira, Chemical and antioxidant properties of wild edible mushrooms from native nothofagus spp. forest, Argentina, Molecules, 2016, 21, 1-15.

15 C. Barroetaveña and C. V. Toledo, in Wild Plants, Mushrooms and Nuts: Functional Food Properties and Applications, ed. I. C. F. R. Ferreira, P. Morales and L. Barros, John Wiley \& Sons, Ltd., 2017, pp. 65-81.
16 E. Boa, Wild edible fungi: A global overview of their use and importance to people, FAO, Rome, Italy, 2004.

17 Y.-C. Dai, Z.-L. Yang, B.-K. Cui, C.-J. Yu and L.-W. Zhou, Species Diversity and Utilization of Medicinal Mushrooms and Fungi in China (Review), Int. J. Med. Mushrooms, 2009, 11, 287-302.

18 P. Kalac, Chemical composition and nutritional value of European species of wild growing mushrooms: A review, Food Chem., 2009, 113, 9-16.

19 M. Gąsecka, M. Siwulski and M. Mleczek, Evaluation of bioactive compounds content and antioxidant properties of soil-growing and wood-growing edible mushrooms, J. Food Process. Preserv., 2017, e13386.

20 V. Lobo, A. Patil, A. Phatak and N. Chandra, Free radicals, antioxidants and functional foods : Impact on human health, Pharmacogn. Rev., 2010, 4, 118-126.

21 I. C. F. R. Ferreira, J. A. Vaz, M. H. Vasconcelos and A. Martins, Compounds from Wild Mushrooms with Antitumor Potential, Anticancer Agents Med. Chem., 2010, 10, 424-436.

22 F. S. Reis, A. Martins, M. H. Vasconcelos, P. Morales and I. C. F. R. Ferreira, Functional foods based on extracts or compounds derived from mushrooms, Trends Food Sci. Technol., 2017, 66, 48-62.

23 F. Souilem, Â. Fernandes, R. C. Calhelha, J. C. M. Barreira, L. Barros, F. Skhiri, A. Martins and I. C. F. R. Ferreira, Wild mushrooms and their mycelia as sources of bioactive compounds: Antioxidant, anti-inflammatory and cytotoxic properties, Food Chem., 2017, 230, 40-48.

24 Â. Fernandes, J. Petrović, D. Stojković, L. Barros, J. Glamočlija, M. Soković, A. Martins and I. C. F. R. Ferreira, Polyporus squamosus (Huds.) Fr from different origins: Chemical characterization, screening of the bioactive properties and specific antimicrobial effects against Pseudomonas aeruginosa, LWT-Food Sci. Technol., 2016, 69, 91-97.

25 O. Taofiq, A. Martins, M. F. Barreiro and I. C. F. R. Ferreira, Anti-inflammatory potential of mushroom extracts and isolated metabolites, Trends Food Sci. Technol., 2016, 50, 193-210.

26 L. Barros, B. A. Venturini, P. Baptista, L. M. Estevinho and I. C. F. R. Ferreira, Chemical Composition and Biological Properties of Portuguese Wild Mushrooms : A Comprehensive Study Chemical Composition and Biological Properties of Portuguese Wild Mushrooms, J. Agric. Food Chem., 2008, 56, 3856-3862.

27 L. Barros, R. C. Calhelha, J. A. Vaz, I. C. F. R. Ferreira, P. Baptista and L. M. Estevinho, Antimicrobial activity and bioactive compounds of Portuguese wild edible mushrooms methanolic extracts, Eur. Food Res. Technol., 2007, 225, 151-156.

28 M. Soković, A. Ćirić, J. Glamočlija and D. Stojković, in Wild Plants, Mushrooms and Nuts: Functional Food Properties and Applications, ed. I. C. F. R. Ferreira, P. Morales and L. Barros, John Wiley \& Sons, Ltd., 2017, pp. 83-122.

29 M. J. Alves, I. C. F. R. Ferreira, J. Dias, V. Teixeira and A. Martins, A Review on Antifungal Activity of Mushroom 
Extracts and Isolated Compounds.Pdf, Planta Med., 2012, 78, 1707-1718.

30 D. S. Stojković, N. Kovačević-Grujičić, F. S. Reis, S. Davidović, L. Barros, J. Popović, I. Petrović, A. Pavić, J. Glamočlija, A. Ćirić, M. Stevanović, I. C. F. R. Ferreira and M. Soković, Chemical composition of the mushroom Meripilus giganteus Karst. and bioactive properties of its methanolic extract, LWT-Food Sci. Technol., 2017, 79, 454-462.

31 Y. Zhao, R. Xie, X. Chao, Y. Zhang, R. Lin and W. Sun, Bioactivity-directed isolation, identification of diuretic compounds from Polyporus umbellatus, J. Ethnopharmacol., 2009, 126, 184-187.

32 T. Ohsawa, M. Yukawa, C. Takao, M. Murayama and H. Bando, Studies on constituents of fruit body of Polyporus umbellatus and their cytotoxic activity, Chem. Pharm. Bull., 1992, 40, 143-147.

33 D. Y. Uan, J. M. Ori, K. K. Omatsu, T. M. Akino and Y. K. Ano, An Anti-aldosteronic Diuretic Component (Drain dampness) in Polyporus Sclerotium, Biol. Pharm. Bull., 2004, 27, 867-870.

34 Y. Zhao, Traditional uses, phytochemistry, pharmacology, pharmacokinetics and quality control of Polyporus umbellatus (Pers.) Fries : A review, J. Ethnopharmacol., 2013, 149, 35-48.

35 Y. Zhao, X. Chao, Y. Zhang, R. Lin, U. Pierre, M. Curie-paris and I. P. De Chimie, Cytotoxic Steroids from Polyporus umbellatus, Planta Med., 2010, 76, 1755-1758.

36 I. Akata, B. Ergönül and F. Kalyoncu, Chemical Compositions and Antioxidant Activities of 16 Wild Edible Mushroom Species Grown in Anatolia.pdf, Int. J. Pharmacol., 2012, 8, 134-138.

37 M. Dimitrijevic, S. Jovanovic, J. Cvetkovic and T. Mihajilov-, Analytical Methods antiradical activities of twelve selected Serbian wild, Anal. Methods, 2015, 7, 4181-4191.

38 M. Elmastas, O. Isildak, I. Turkekul and N. Temur, Determination of antioxidant activity and antioxidant compounds in wild edible mushrooms, J. Food Compos. Anal., 2007, 20, 337-345.

39 A. A. Babakhin, N. Y. Logina, H. Nolte and L. M. DuBuske, Immunomodulating Activity of the Extract from High Mycelium Fungus Polyporus Squamosus, J. Allergy Clin. Immunol., 1996, 97, 229.

40 N. Dursun, M. M. Öycan, G. KaŞık and C. Öztürk, Mineral contents of 34 species of edible mushrooms growing wild in Turkey, J. Sci. Food Agric., 2006, 86, 1087-1094.

41 P. G. Ergönül, I. Akata, F. Kalyoncu and B. Ergönül, Fatty Acid Compositions of Six Wild Edible Mushroom Species, Sci. World J., 2013, 2013, 163964.

42 M. Kostic, M. Smiljkovic, J. Petrovic, J. Glamocilija, L. Barros, I. C. F. R. Ferreira, A. Ciric and M. Sokovic, Chemical, nutritive composition and wide-broad bioactive properties of honey mushroom Armillaria mellea (Vahl: Fr.) Kummer, Food Funct., 2017, 8, 3239-3249.

43 F. S. Reis, D. Sousa, L. Barros, A. Martins, P. Morales, I. C. F. R. Ferreira and M. H. Vasconcelos, Leccinum vulpi- num Watling induces DNA damage, decreases cell proliferation and induces apoptosis on the human MCF-7 breast cancer cell line, Food Chem. Toxicol., 2016, 90, 45-54.

44 AOAC, Official Methods of Analysis of AOAC International, 20th edn, 2016.

45 C. Grangeia, S. A. Heleno, L. Barros, A. Martins and I. C. F. R. Ferreira, Effects of trophism on nutritional and nutraceutical potential of wild edible mushrooms, Food Res. Int., 2011, 44, 1029-1035.

46 D. S. Stojković, L. Barros, R. C. Calhelha, J. Glamočlija, A. Ćirić, L. J. L. D. van Griensven, M. Soković and I. C. F. R. Ferreira, A detailed comparative study between chemical and bioactive properties of Ganoderma lucidum from different origins, Int. J. Food Sci. Nutr., 2014, 65, 42-47.

47 L. Barros, M. Dueñas, I. C. F. R. Ferreira, P. Baptista and C. Santos-Buelga, Phenolic acids determination by HPLC-DAD-ESI/MS in sixteen different Portuguese wild mushrooms species, Food Chem. Toxicol., 2009, 47, 1076-1079.

48 L. Barros, C. Pereira and I. C. F. R. Ferreira, Optimized analysis of organic acids in edible mushrooms from portugal by ultra fast liquid chromatography and photodiode array detection, Food Anal. Methods, 2013, 6, 309-316.

49 S. A. Heleno, L. Barros, M. J. Sousa, A. Martins and I. C. F. R. Ferreira, Tocopherols composition of Portuguese wild mushrooms with antioxidant capacity, Food Chem., 2010, 119, 1443-1450.

50 F. S. Reis, S. A. Heleno, L. Barros, M. J. Sousa, A. Martins, C. Santos-Buelga and I. C. F. R. Ferreira, Toward the Antioxidant and Chemical Characterization of Mycorrhizal Mushrooms from Northeast Portugal, J. Food Sci., 2011, 76, 824-830.

51 Methods for Dilution Antimicrobial Susceptibility Tests for Bacteria That Grow Aerobically; Approved Standard, Clinical and Laboratory Standards Institute, Wayne, PA, 8th edn, 2009, vol. 29.

52 T. Tsukatani, H. Suenaga, M. Shiga, K. Noguchi, M. Ishiyama, T. Ezoe and K. Matsumoto, Comparison of the WST-8 colorimetric method and the CLSI broth microdilution method for susceptibility testing against drugresistant bacteria, J. Microbiol. Methods, 2012, 90, 160-166.

53 A. L. Spoering and K. I. M. Lewis, Biofilms and Planktonic Cells of Pseudomonas aeruginosa Have Similar Resistance to Killing by Antimicrobials, J. Bacteriol., 2001, 183, 67466751.

54 E. Drenkard and F. M. Ausubel, Pseudomonas biofilm formation and antibiotic resistance are linked to phenotypic variation, Nature, 2002, 416, 740-743.

55 C. O'May and N. Tufenkji, The swarming motility of Pseudomonas aeruginosa is blocked by cranberry proanthocyanidins and other tannin-containing materials, Appl. Environ. Microbiol., 2011, 77, 3061-3067.

56 G. A. O'Toole and R. Kolter, Flagellar and twitching motility are necessary for Pseudomonas aeruginosa biofilm development, Mol. Microbiol., 1998, 30, 295-304.

57 S. S.-M. Yeo and F.-Y. Tham, Anti-quorum sensing \& antimicrobial activities of some traditional Chinese medicinal 
plants commonly used in South-East Asia, Malays. J. Microbiol., 2012, 8, 11-20.

58 A. Espinel-Ingroff, Comparison of the E-test with the NCCLS M38-P method for antifungal susceptibility testing of common and emerging pathogenic filamentous fungi, J. Clin. Microbiol., 2001, 39, 1360-1367.

59 A. Begic-Akagi, N. Spaho, F. Gasi, P. Drkenda, A. Vranac and M. Meland, Sugar and organic acid profiles of the traditional and international apple cultivars for processing, J. Hyg. Eng. Des., 2014, 7, 190-196.

$60 \mathrm{X}$. Wu, J. Cheng and X. Wang, Dietary Antioxidants: Potential Anticancer Agents, Nutr. Cancer, 2017, 69, 521-533.

61 D. Huang, O. U. Boxin and R. L. Prior, The chemistry behind antioxidant capacity assays, J. Agric. Food Chem., 2005, 53, 1841-1856. 